\title{
Introduction: Roots of conflict in the Southern Highlands
}

\author{
Nicole Haley and Ronald J. May
}

For a number of years the Southern Highlands Province (SHP) has been riven by conflict. Longstanding inter-group rivalries, briefly set aside during the colonial period, have been compounded by competition for the benefits provided by the modern state and by fighting over the distribution of returns from the several big mining and petroleum projects located within the province or impinging upon it. ${ }^{1}$ According to some reports, deaths from the various conflicts in the province over the past decade number in the hundreds. ${ }^{2}$ As a result of inter-group fighting, criminal activity, vandalism and politically motivated actions, a number of businesses, banks and post offices throughout the province have ceased operating. There are no longer any banking and postal facilities outside the Mendi area. As at September 2004 the Mendi branch of Bank South Pacific was the only remaining commercial banking facility in the province, and several large business houses had shut. Best Buy Mendi and the Coca Cola depot both shut in September 2004, resulting in more than 100 jobs lost. Business leaders attributed these business closures to ongoing law and order problems and a dwindling cash economy (Post-Courier 24 September 2004). Schools, vocational and training colleges, health centres, hospitals, and guesthouses have closed, sometimes temporarily, often permanently. As at August 2004, Minister for Inter-Government Relations, Sir Peter Barter, reported that 11 of the 12 high schools and all of the secondary schools in Southern Highlands Province were shut (Post-Courier 05 August 2004). Dauli teachers college and the Mendi school of nursing remain shut, and Tari hospital is without a doctor. On several occasions government offices in Mendi and Tari have been burned down or destroyed by the supporters of disgruntled political candidates. In December 2002, for instance, fourteen government offices in Mendi were destroyed by fire (Post-Courier 9 December 2002). Roadblocks and ambushes have made travel dangerous in many parts of the province and almost all scheduled passenger flights have been cancelled. Expatriate missionaries, volunteers and aid workers have been withdrawn from the province; and for some time Australia's Department of Foreign Affairs and Trade travel advisories have specifically warned visitors to Papua New Guinea against travel to the Southern Highlands. Very few public servants can be found at their posts (although thousands remain on the payroll), and state services have ground to a halt. Corruption is rife. The authority of the state in the Southern Highlands has been regularly challenged and police are often reluctant to act because they are outnumbered and outgunned. The costs 
in both human and material terms have been substantial. Minister for Inter-Government Relations, Sir Peter Barter, is reported to have said that SHP is at risk of becoming 'a failed province' (Post-Courier 21 October 2002).

The problems that have beset SHP were highlighted during Papua New Guinea's 2002 national elections, which were characterised by violence and malpractice of a scale never before seen in Papua New Guinea (Standish 2000). Even in the context of national elections now characterised by 'gunpoint democracy' (Standish 1996, 2000), the Southern Highlands elections were particularly violent. A number of people (including police) were killed; a high profile candidate was kidnapped and held for ransom; all airstrips in the western end of the province were closed following threats that planes would be shot out of the sky, and people throughout the province were threatened and intimidated by wealthy candidates and their supporters, often armed with high-powered weapons (Haley 2004). In July 2002, following clarification from the Supreme Court of Papua New Guinea, the 2002 national elections were deemed to have failed in six of the SHP's nine electorates, leaving the greater part of the province's population without political representation for some ten months.

The declaration that the SHP elections had failed resulted in widespread confusion and a further escalation of violence throughout the province. Disgruntled electors felled dozens of power pylons between Nogoli and Porgera and production at the Porgera Gold Mine in Enga Province consequently had to be suspended for three months (see Lavu, this volume). Thousands of employees were stood down and much revenue was lost. In the weeks following the election the leading candidates in the six undeclared SHP seats declared themselves to be duly elected to parliament (Post-Courier 5 August 2002). They and their supporters subsequently threatened disruption of the province's resource projects and promised to 'bring the nation to its knees' if their demands to be sworn in were not acceded to (Post-Courier 9 August 2002). The group of six also wrote to the Prime Minister, Sir Michael Somare, threatening that the SHP would secede. John Honale, a spokesman for the group's supporters, was reported to have said:

I'm giving the Somare-led government until $4.06 \mathrm{pm}$ tomorrow to declare the remaining six seats ... If we don't have a reply [to the above mentioned letter] by 4.06 (close of business) tomorrow, then the Southern Highlanders will become a republic country ... More people will die. Roads will be blocked; more bridges will be blown up (Post-Courier 9 August 2002).

Despite this pressure, the six leading candidates were not sworn in. They and their supporters were forced to wait a further nine months for fresh elections. During this time much energy was spent restoring law and order within the province, in preparation for the supplementary elections. 
Supplementary elections were held in the Southern Highlands in April/May 2003. The Electoral Commission managed these elections with the assistance of 2000 additional police, soldiers and prison warders. Despite the additional security presence, the elections were still marred by violence and irregular voting. Large numbers of extra votes were cast in the Nipa-Kutubu and Koroba-Lake Kopiago electorates and many people were unable to vote due to intimidation or because candidates and their core supporters filled out the ballot papers themselves (Post-Courier 12 May 2003). During the count a polling official was beaten in front of international observers (Post-Courier 7 May 2003) and three weeks later the same man was killed. Initial reports implicated the security forces in his death (Post-Courier 30 May-1 June 2003).

\section{The place of conflict in SHP}

Goldman (this volume) reminds us that conflict is an integral part of life in the Southern Highlands: 'fighting is both a recurrent and legitimate means of prosecuting claims or seeking restitution' in many Papua New Guinean societies. Conflict per se is not considered inimical to social order. Rather, what is important is the way people engage with, handle, and control conflict in a particular context. When controlled and properly contained, conflict is a major feature of sociality in the Southern Highlands. It is unmediated conflict which is problematic. This is a key to understanding the problems facing the Southern Highlands, for there seems to be a diminished capacity to control and contain conflict in the contemporary context.

During the workshop discussion, James Weiner argued that disjunctures between the state and local conceptions of exchange and personhood have served to exacerbate local tensions, contributing to increasingly unmanageable social relations. He noted that the Foi (Southern Highlanders from the Lake Kutubu area) traditionally responded to conflict and unmanageable social relations by dissolving clan ties and moving or relocating. Social life, he observed, was more fluid prior to the imposition of the state, and people had at their disposal dispute-resolution strategies which allowed them to interrupt or contain conflict. The effects of representative politics and land registration in the context of resource development have, however, countervailed the impulse to disaggregate and increased the potential for conflict.

Moreover, traditional dispute resolution mechanisms are not equipped to counter new forms of fighting, which are larger in scale, more violent, and involve high-powered weapons. Traditional dispute resolution mechanisms are necessarily limited, and incapable of dealing with the widespread nature of modern warfare. 


\section{The changing nature of conflict in SHP}

Several of the workshop participants, especially those who had worked in Papua New Guinea before independence, noted that the Southern Highlands was relatively quiet through the 1970s and 1980s, and that fighting, when it occurred at that time, was usually contained. This was due in part to the fact that many young men were employed outside the province, initially through the Highlands Labour Scheme and because kiaps continued to coordinate and dominate activities in the Southern Highlands well into the 1970s (Ballard 1983:175).

Throughout the 1990s, however, fighting in the Southern Highlands became increasingly violent and protracted, so much so that lawlessness now prevails in many areas. The upsurge in fighting in SHP seems to have coincided with the advent of large-scale resource development projects. Indeed many of the ongoing conflicts concern the distribution of oil and gas royalties and access to project-related benefits. Concomitant with this, many of the workshop participants observed that in the past 15 years or so new-style leaders have emerged and they, along with the younger generation of which they are a part, have come to disregard the norms, values and mechanisms of dispute settlement upheld by the older generation (see Walters, this volume). This has resulted in a situation in which communities are less able to manage conflict.

In the context of resource development, traditional leadership roles have been reassessed, such that young educated men, perceived to be better able to communicate with company representatives, have assumed leadership roles in many cases to the detriment of their communities. While these new leaders may well have a good command of English, they often lack the leadership skills needed for effective conflict management. Instead of employing oratory to resolve disputes, they rely increasingly on high-powered weapons. In the Southern Highlands today, the majority of adult men either own or have access to a home-made shot gun if not an imported weapon. The prevalence of high-powered weapons throughout the province has meant that the police are often out-gunned and therefore reluctant to tackle the escalating law and order problems.

The past 15 years have also seen the advent of more insidious forms of violence. Goldman (this volume) observes that new forms of injury, including maiming, are now being perpetrated and that armed raskol gangs roam the province. In some cases 'hired guns' have been brought into the conflict by warring groups. Some groups within the Southern Highlands have begun to employ terrorist tactics, such as kidnapping and demanding ransom (Haley 2004).

\section{Roots of conflict in the Southern Highlands}

Without exception participants at the workshop agreed, notwithstanding the traditional sociality of conflict, that conflict is a serious impediment to 
development and that the situation in the Southern Highlands is in urgent need of redress. There is a comprehensive breakdown of law and order, and state service provision has all but ceased. The past 15-20 years have seen public servants move in the first instance to larger centres and more recently to other provinces, where they can secure basic services for their own families.

Why is the situation in the Southern Highlands so poor? One of the recurring observations made by workshop participants was that the problems in SHP do not relate to lack of income as such, but to the distribution and reinvestment of that income. This view is endorsed by Sir Peter Barter. In a press release dated 24 February 2003, he noted that SHP is the richest province 'because of the flow from the oil and gas projects' and the poorest province 'because those resources have been squandered'. The widespread mismanagement and misappropriation of government funds as well as oil and gas royalties has meant that although the Southern Highlands is home to several of Papua New Guinea's successful resource projects, the majority of Southern Highlanders have gained little benefit from the projects being undertaken in their province. This is a source of ongoing discontent within the province. One often hears Southern Highlanders ask: why is SHP so disadvantaged relative to other parts of Papua New Guinea when it is home to many of the country's resource projects? In the words of James Marape, a candidate for the Tari Open electorate in 2002:

Something has to be done because we are contributing so much to this country's economy and there is no justification in the distribution of government services back into our part of the province (Independent 28 August 2002).

Clearly, a major source of conflict in the Southern Highlands is inequitable access to state services and to the 'benefits' of resource development. Other sources of tension and conflict include ethnic divisions, lack of effective administration and governance, and unrealistic expectations about resource development.

\section{Background}

SHP, one of Papua New Guinea's largest provinces, and its most populous, comprises eight districts - Koroba-Lake Kopiago, Tari-Pori, Komo-Magarima, Nipa-Kutubu, Mendi, Imbonggu, Ialibu-Pangia and Kagua-Erave - occupying $25,700 \mathrm{~km}^{2}$. It is presently home to an estimated 500,000 people. ${ }^{3}$ Much of the province is poorly suited to agriculture and more than half the province presently remains unoccupied for this reason (Hanson et al 2001 and see Allen, this volume). The Southern Highlands accounts for 11 per cent of Papua New Guinea's rural population (ibid:91) and 10.6 per cent of Papua New Guinea's total population (National Census 2000). 
Figure 1.1. Resource development in PNG including Southern Highlands Province

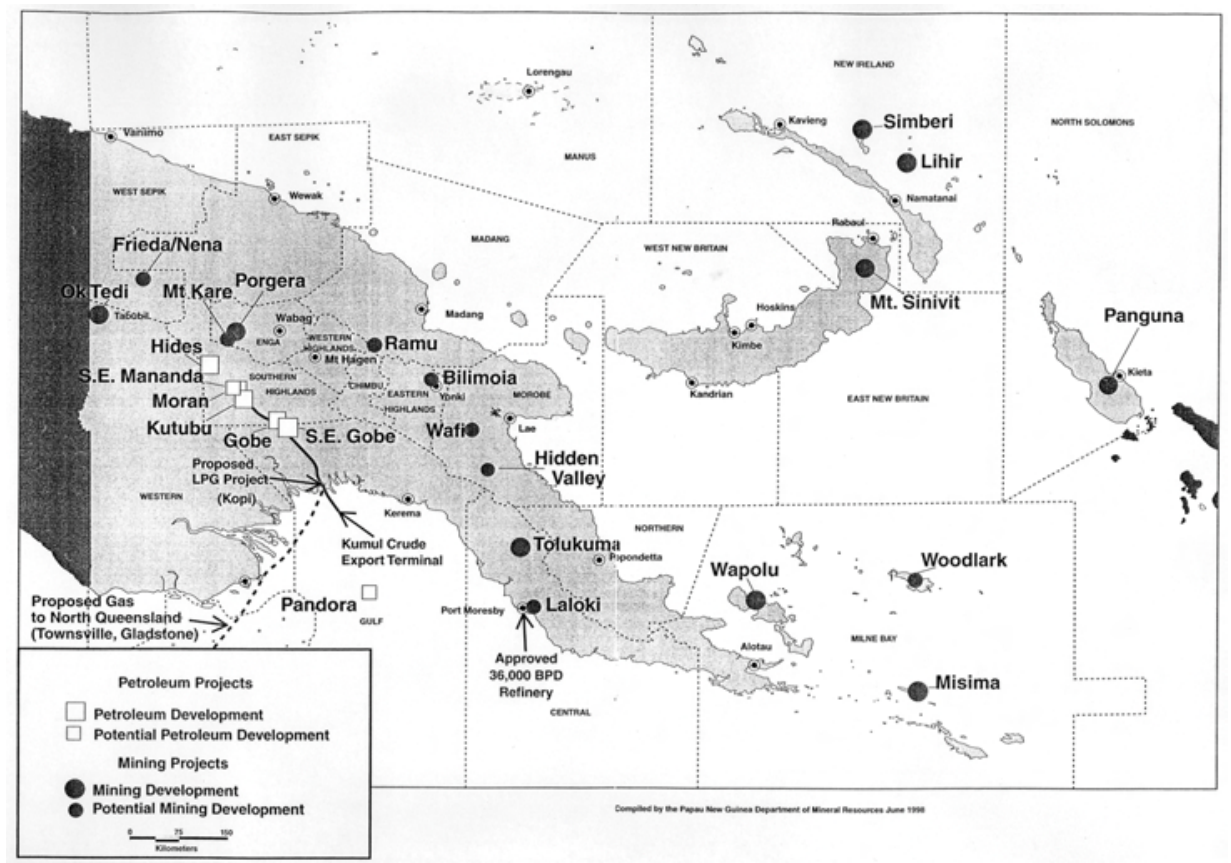

For the most part, the peoples of SHP are concentrated in the central and eastern parts of the province. They tend to live in dispersed households rather than in nucleated settlements or villages, and this makes service delivery somewhat more difficult than in other areas. The Tari Basin and Nembi Plateau are the most densely populated parts of the province (190 persons $/ \mathrm{km}^{2}$ ), closely followed by the Upper Mendi and Lai Valleys (120 persons $/ \mathrm{km}^{2}$ ) (Hanson et al 2001:91; Bourke et al 1995:27). High density populations (61-100 persons $/ \mathrm{km}^{2}$ ) are also found around Ialibu, between Mendi and Kagua, between Nipa and Magarima, in the Wage Valley, on the Paijaka Plateau and in the Koroba, Komo and Benaria areas. By contrast, the Erave, Bosavi, Kutubu and Lake Kopiago areas, located to the south and northwest of the province, are only moderately populated, while the Lebani Valley, Yeru/Bogaia and Hewa areas are only very sparsely populated (less than 5 persons $/ \mathrm{km}^{2}$ ). The highest populations are found where land potential is the greatest, so there is limited potential for further agricultural growth within the province.

\section{Inequitable access to services}

Southern Highlanders experience differential access to services. Nowadays, only the most densely populated areas of the Southern Highlands are connected by the existing road system. The more remote outlying areas are accessed only by 
air or by foot; in many cases, roads formerly maintained have been allowed to fall into such a state of disrepair that they are no longer open to vehicular traffic. A case in point is the loop road from Koroba to Lake Kopiago.

Twenty per cent of the province's population (approx 100,000 people) now live in places which are accessible only by air. ${ }^{4}$ For these people it is increasingly difficult to access their provincial headquarters in Mendi and/or a major service centre such as Mount Hagen. There are no longer regular passenger flights between Mendi and the western end of the province, and the cost of flying has risen astronomically. Whereas people living in the central and eastern end of the province (Mendi, Ialibu and Kagua) can access Mount Hagen in less than three hours by way of a K10 PMV (Passenger Motor Vehicle) ride, people living in Bosavi and the remote western end of the province must rely on air travel which is increasingly beyond their reach. For example, it now costs K388 to fly one-way from Lake Kopiago to Mt Hagen while less than ten years ago it cost only K70 to fly from Lake Kopiago to the provincial headquarters.

To put this further in perspective, incomes throughout the Southern Highlands are typically low to very low, for the most part being less than K20 person/year. The exceptions to this are the areas around Kutubu, Pangia and Mendi, where incomes are moderate, being in the order of K41-100 person/year (Hanson et al 2001:91), due to oil and gas royalties, coffee sales and the diversion of government funds respectively. The average person in the Southern Highlands can no longer afford to fly.

Consideration of access and income leads directly to the subject of disadvantage. A recent study by Hanson et al (2001) calculated an index of disadvantage for each district of Papua New Guinea, based on five parameters: land potential, agricultural pressure, access to services, income from agriculture, and child malnutrition. The study suggested that people living within the Koroba-Lake Kopiago and Nipa-Kutubu districts were 'extremely disadvantaged' (thirteen districts in the country were classified as 'extremely disadvantaged') and that people living in the Komo-Magarima and Kagua-Erave districts were seriously disadvantaged relative to the national average. The study also observed that the Koroba-Lake Kopiago and Nipa-Kutubu districts have been found to be among the twenty most disadvantaged districts in three separate studies over a 25-year period (Wilson 1974; de Albuquerque and D'Sa 1986; Hanson et al 2001).

Thus the 100,000 or so people living in the remote areas of SHP are not just the most disadvantaged and disenfranchised within the province, but are some of the most disadvantaged in Papua New Guinea. These peoples live in poor environments and have low incomes and very poor access to services. They lack schools and health facilities and cannot retain public servants posted there. They are among the most vulnerable in Papua New Guinea with respect to long-term food security (Bourke 2001:11). There are several reasons for this disadvantage, 
the most significant being demography and remoteness, which conspire to render service provision expensive and difficult. Hanson et al (2001:304) note that the most disadvantaged districts tend to be located adjacent to provincial borders, and that the peoples living in such areas tend to be ignored by all provincial administrations. The devaluation of the national currency and the concomitant rise in the cost of air travel have served to further isolate these areas. Local trade stores have ceased to operate due to exorbitant transportation costs, and most of the public servants have absconded. Remoteness, coupled with poor business skills, has contributed to the failure of commercial agricultural ventures such as cattle, coffee and chillies.

The situation in the Lake Kopiago sub-district provides a snapshot of what life is like for Southern Highlanders living in the remote rural parts of the province. As one moves northwest from Tari, what little infrastructure there is in the province completely dissipates. For example, the reasonably well-maintained and graded roads and iron bridges of the Tari and Koroba areas give way to a 4WD track with log bridges, and thence to barely-defined walking tracks. There is no health extension officer at the sub-district health centre, the last one having left in 1996; the local nurses and health workers posted to the area have since relocated to Mount Hagen, as have the school teachers. There are no police or village court magistrates. Health and immunisation patrols have ceased, and formal education is at risk of being completely phased out.

It is now 15 years since Lake-Kopiago Community School (now a top-up primary) has had a full compliment of teachers, and there is a whole generation of children who have had no formal schooling. More critical, though, is the fact that the implementation of an elementary school system has stalled. Years 1, 2 and 3 were suspended in 1999 under the New Education Reforms; no elementary schools have been formally registered and no training of teachers has taken place within the Lake Kopiago sub-district. In fact, there have been no lower-level primary classes in the sub-district for five years. In the remote areas of SHP the education reforms have done nothing more than formally phase out education.

Much has been made of Governor Hami Yawari's free education policy launched in February 2004, but even this has done little to improve the situation in the most remote parts of the province, where schools remain shut due to teacher shortages and absences.

With road closures and the rising cost of air travel, local cash economies have all but ceased to function in many areas. Indeed, whereas in the mid 1990s one could buy all manner of store goods in the half dozen or so large trade stores then operating on Kopiago station, now there is nothing. With the closure of trade stores, local markets have also ceased to function, as there is no incentive for men and women to sell local produce. These developments have important implications for food security, as there is now far less capacity to deal with 
large-scale environmental hazards, such as drought. As Bourke (2001:11) has observed, low cash incomes represent a major threat to food security in the longer term.

That districts such as Koroba-Lake Kopiago, Komo-Magarima, Nipa-Kutubu and Kagua-Erave rate amongst the poorest in Papua New Guinea, is of concern for many reasons, not least because several resource projects are situated within SHP. This is an ongoing source of discontent at many levels within the province. Southern Highlanders often complain that they have not benefited from the oil and gas production going on in their province. It is this discontent which has fuelled the calls for a Hela Province, and which led to the formation of the United Resources Party (see Haley, this volume). Various groups within the Southern Highlands hold the view that others within the province have benefited disproportionately from resource development projects, and this too is a source of ongoing discontent. In part these complaints can be explained in terms of unrealistic expectations, but it remains the case that the various resource projects within SHP have failed to alleviate rural poverty or reduce the overall level of disadvantage of the districts in which they are situated. ${ }^{5}$ Likewise, they have failed to bring about local-level development.

\section{Ethnic tensions and lack of effective administration and governance}

A quite different type of conflict both within the province and within individual districts can be attributed to ethnic tensions. Electoral boundaries within SHP do not coincide with ethnic ones. Huli speakers, for instance, are found not only in Tari district, but also in the Koroba-Lake Kopiago, Komo-Magarima and Nipu-Kutubu districts. Likewise, Mendi speakers are found not only in the Mendi district but also in the Nipa-Kutubu and Imbonggu districts. Even smaller groups such as the Duna, who number about 30,000, are split between districts, with three quarters of their population in the Koroba-Lake Kopiago district and the remaining quarter in the Tari district.

There are at least 16 languages spoken within SHP. Of these, the big three - Huli $(140,000)$, Mendi $(115,000)$ and Kewa $(100,000)$ - account for more than 70 per cent of the province's population. This in itself has created much political tension over the years as elected representatives from the various groups have jostled to establish themselves at the top of the province's pecking order. It has also seen the province divide politically, with the Huli-speaking areas of Koroba-Tari-Komo-Magarima in the west, the Mendi-speaking Mendi and Nipa areas in the centre, and Imbonggu and Kewa-speaking Ialibu-Kagua area in the east. These divisions are reflected in current administration policy such that there are assistant provincial administrators for the western end, eastern end and Mendi central area respectively. 


\section{Figure 1.2. Southern Highlands agricultural systems and cultural groups}

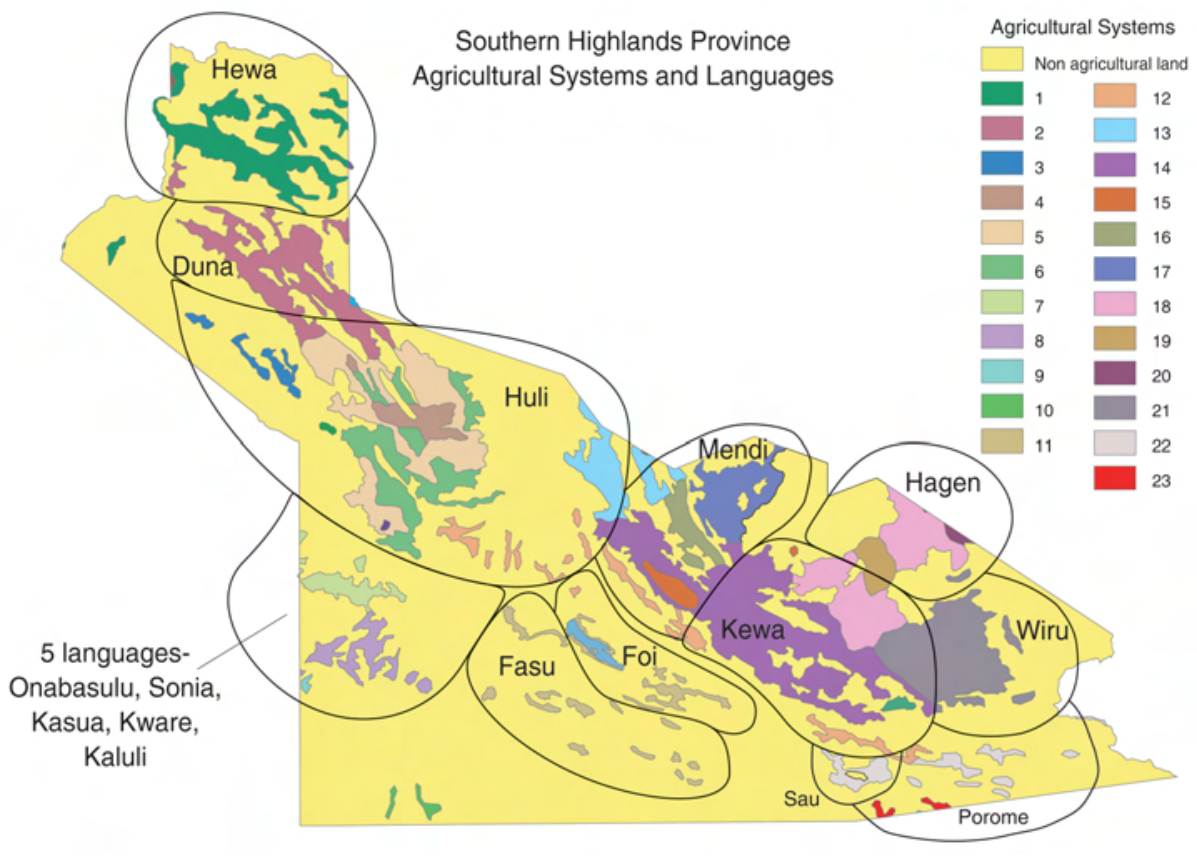

Conflict between the west, the centre, and east of the province has raged for many years, resulting in fighting and road closures in and around Nipa and Magarima. Much of the fighting in recent years has revolved around allegations concerning the death of the former governor, Dick Mune. It was alleged that Mune (from Nipa), who died in a car accident, had in fact been killed by Anderson Agiru, the Huli man who succeeded him as governor in 1997. Specifically, it was rumoured that Anderson Agiru had employed sorcery techniques obtained in the east to bring about Mune's death. Following Mune's death the Nipa people blocked the highway, thereby denying Hulis access to Mendi, the provincial headquarters, and interrupting service provision to the western end of the province.

Such rumour, innuendo and conflict are not entirely new. In July 1980 when the then provincial premier Andrew Andaija died in a plane crash, less than a month after being re-elected, the Huli refused to accept that his death was an unfortunate accident. Instead they blamed the people of Ialibu, Pangia, Kagua and Erave, alleging that some form of sorcery or poison had been used to bring the plane down. Andrew Andaija's death, like Dick Mune's, fuelled east-west animosity and resulted in ongoing conflict. In the months following Andaija's death, Hulis attempted to kill the then member for Imbonggu, Glaimi Warena, and were also allegedly responsible for an incident in which Wiwa Korowi was stoned in Port Moresby. At the time, the Post-Courier reported that 'east-west 
animosity between the people of the Southern Highlands is emerging as a serious threat to harmony in the province' (Post-Courier 21 August 1980:19).

Ethnic conflicts across the province such as this between the Hulis and Mendis, as well as smaller-scale conflicts at the district level, have proved a significant impediment to effective administration. The result is that the province's ethnic minorities have continually been denied services by their political representatives, who have until now almost always been members of the dominant ethnic groups. ${ }^{6}$

Governance in the Southern Highlands is severely compromised. The past two decades have seen the effectiveness of the courts, police and law enforcement agencies stripped away (see Bragge, Goldman and Warrilow, this volume). The administration has lost the capacity to deal with the province's problems, due in part to ongoing political interference and a lack of administrative accountability.

At the provincial level, jockeying for control of the province between the Huli speakers in the west, the Mendi speakers in the central area and the Kewa-speaking peoples of the east has led to the formation of competing administrations; this has proved an impediment to effective administration and good governance. All too often administrative appointments in the Southern Highlands have been made on the basis of ethnicity and this has resulted in tit-for-tat sackings and reappointments over many years. At present, there are not only new administrative appointees but also people appointed by the two previous governors (Dick Mune and Anderson Agiru) and the various interim administrations of SHP, all of whom claim to hold the same positions. Indeed, at one point not long ago, four different men were being paid as administrator of the SHP. Many people politically aligned with and employed under Dick Mune's administration remain on the government payroll, as do those loyal to and appointed by Anderson Agiru. Under Anderson Agiru's administration many public servants from the western end of the province were transferred into the Ialibu-Pangia area, thereby aggravating tensions between the eastern and central areas. And during the period of the interim administration, people from the eastern end of the province were appointed to positions in the west.

As well as the inevitable tensions this creates, government expenditure is in consequence far greater than it need be, especially when, as is often the case, none of the public servants appointed to a position is actually doing the job he or she is paid for. For example, the Assistant District Administrator (ADA) officially appointed to Lake Kopiago has never taken up his posting there, although he continues to draw his salary as if he were the ADA. He refused to take up his posting to Kopiago, after being threatened by Anderson Agiru's supporters. $^{7}$ The man who has for the past six years paraded himself as ADA is a former community school teacher with no administrative training appointed 
by Anderson Agiru. Most government appointments throughout the province appear to be duplicated in this way, and most are political appointments. During the period 1997-2002 there were two competing administrations in Koroba-Lake Kopiago District - one established by the national MP, Herowa Agiwa, and another by former governor, Anderson Agiru. All the public servants politically appointed during this period appear to continue to draw government salaries.

Added to this is the problem of village-based appointments. This, too, creates local-level tensions. In the absence of the public servants appointed to various positions, local communities have often appointed community leaders to undertake responsibilities. In the Kopiago sub-district, for example, peace and good order committees, village magistrates and lands mediators have been appointed by villagers. None of these people get paid for the work they do. Yet their appointed counterparts sit in Mendi and Mount Hagen and get paid for doing nothing. This creates resentment in the village.

Good governance in the Southern Highlands is also impeded by entrenched corruption at all levels of government, and the presence of high-powered weapons throughout the province. For the most part it is the elected representatives and their fellow candidates who have added the weapons to the mix of ethnic tensions and brewing resentments. In the lead-up to both the 1997 and 2002 national elections, prominent candidates stockpiled weapons and distributed them amongst their supporters. In one case, a prominent candidate flew in cartons of semi-automatic weapons purchased in China while on an official government visit, so that his supporters might usurp control of the elections on polling day. And in the lead-up to polling in the failed 2002 elections, Stanley Kotange, the district administrator for Koroba-Lake Kopiago, wrote to the Mission Aviation Fellowship (MAF), Hevilift and various other air charter companies, warning that local candidates and their supporters were in possession of AK47s, M16s, M202s, SLRs and 303 rifles as well as hand-held rocket launchers and that they intended to shoot down any planes or helicopters attempting to move ballot boxes. Very few of these weapons have been recovered or handed in during the much publicised gun surrenders. Cutting off the flows of money from elected politicians and politically appointed public servants to local militants is crucial to the task of restoring law and order.

\section{Unrealistic expectations about resource development}

Many of the workshop participants, particularly those associated with resource developers, felt that inflated landowner expectations were a source of conflict and potential conflict within the province (see Lavu, this volume). Because of the almost complete absence of functioning state services, resource developers within the Southern Highlands, through their community development programs, have taken on the important role of basic service provision. Ken Logan (Porgera Joint Venture, Community Affairs) noted that frustrated and disgruntled 
landowners often take out their dissatisfaction with the government upon the resource developers. In the period leading up to and following the failed 2002 national elections, Southern Highlanders felled powerlines between Nogoli and Porgera so as to shut down mining operations and hold the government to ransom.

Much of the current conflict associated with resource development projects is directly attributed to state failure: the failure to provide basic services such as health and education; the failure to mediate land and royalty disputes; the failure to address existing law and order problems; the failure to quell unrealistic expectations; and a lack of accountability in relation to the expenditure of funds generated by resource development. Throughout the Southern Highlands one regularly encounters the sentiment that the money being generated through resource development is not being channelled back into rural areas, and this is an ongoing source of discontent.

The state has not only failed to resolve royalty disputes in relation to existing projects, but corrupt politicians and public servants have misused funds generated by the resource projects. An audit of the Southern Highlands administration covering the period 1998 to 2002 revealed a complex pattern of mismanagement and misappropriation involving politicians, public servants, businessmen, and friends of politicians, going back many years. And although this report was released to the fraud squad over two ago, no prosecutions have ensued.

The major resource operations within SHP are now drawing to a close. However, as Lavu (this volume) notes, there is widespread disbelief that this will actually happen. Lavu cites an apparent expectation that the resource developers 'will be there forever' and predicts that such unrealistic expectations will lead not only to disappointment but ongoing conflict. Warrilow (this volume) likewise argues that further resource development on the existing scale is highly unlikely in the current climate, because, although there are several exploration projects underway, there is little likelihood that resource developers will invest, given the current atmosphere of distrust and lawlessness. Future resource development, it seems, will be dependent upon whether the Southern Highlands can be transformed into 'a place where development can take place'.

In the context of resource development, exchange expectations have also been inflated and this has made the management of exchange relations all the more difficult. Compensation and bride price payments have risen exponentially throughout the province, even outside the immediate project areas.

\section{Early predictions}

As O'Collins (this volume) points out, much of SHP came under administrative control very late, and as a result was not derestricted until the mid 1960s, or 
later in the case of the Hewa. ${ }^{8}$ Media and government patrol reports from the late 1960s and early 1970s indicate that the majority of Southern Highlanders did not want self-government or independence, and that while patrol officers in other parts of the country were busy introducing new crops, those in the more remote parts of the SHP were preoccupied with contacting, censusing and giving political education talks to the communities within their jurisdiction. In 1970 the patrol officer at Lake Kopiago observed, 'generally the Tumbudu people have shown little interest in or understanding of the House of Assembly, despite political education talks given on every patrol' (Newell 1970:4).

When Papua New Guinea gained independence there were still no schools in the most remote parts of the Southern Highlands. Those in what is now the Koroba-Kopiago district had been operational for only a decade, and the province's first secondary schools had only been operating eight years. By comparison with other parts of Papua New Guinea, SHP lacked the capacity in terms of qualified personnel - its 'educated elite was both small and dispersed' (Ballard 1983:179) — to govern itself and this has been well reflected in the various crises which have beset the province. The problems which have emerged were in fact predicted by the then House of Assembly members and members of the Southern Highlands District Area Authority, who repeatedly rejected self-government and independence as premature. These members made the Constitutional Planning Committee aware of their views and wrote to the Chief Minister, Michael Somare, and the Australian Prime Minister, Gough Whitlam, urging them to conduct a referendum on the issue of independence. They also made their views public. In the lead-up to independence the councillor for Ialibu was reported as saying:

We aren't ready and don't want it. If we get it now we will go backwards rapidly. Only Moresby and Lae will survive as they will be the last refuges of overseas people, thus the last places with any organisation and efficiency. We in the bush will collapse as the overseas officers leave us (Post-Courier 19 June 1974).

Andrew Andaija, the deputy chair of the Southern Highlands District Area Authority, expressed similar sentiments:

Tari is violently opposed to Independence. All the lying and covering up makes no difference to us. We don't want it and it's no use the Government saying nothing will change after Independence. It obviously will change. Overseas people will leave and we are not capable of replacing them now and won't be for years. Finish the lying and let us get used to self-government and get organised first (Post-Courier 19 June 1974). 
Matiabe Yuwi, the member for Tari-Komo, likewise endorsed the view that the Southern Highlanders lacked the capacity to govern themselves and effectively administer their own province:

This is a big matter. Why don't we want it? We are worried, very worried. We aren't stupid and nor do we say we will never have Independence or that we have to keep the white men forever. But think: communications, education, businesses are non-existent and we have no experienced local public servants to take over ...We have self-government and enough power already but we have no judges, competent military services or experienced men in the field. We will never be satisfied without a referendum. Do we have any Highlanders as directors or heads of departments? No, we don't; we see Tolais, Bukas, some Papuans and others in the big jobs but no Highlanders' (Post-Courier 19 June 1974).

Andrew Wabiria, the MHA for Koroba-Kopiago, was similarly opposed to independence, and publicly urged the Australian government to reverse its policy of withdrawing expatriate officers. He was quoted in the Post-Courier (13 August 1974) as saying, 'experienced expatriate officers are needed in the Southern Highlands District to assist the settlement of land and other disputes'.

That community schools were late to open and have in the past decade closed at an alarming rate, means that literacy levels within the Southern Highlands are low and do not reach more than 50 per cent for males and 30 per cent for females anywhere in SHP (see Allen, this volume). This has ongoing implications for good governance. Throughout much of the Southern Highlands there has been negligible primary education for the past 15 years, resulting in an entire generation of young adults who have missed out on formal schooling. In much of the Southern Highlands literacy levels must be falling, with serious long-term implications for the province.

\section{HIV/AIDS}

Also looming is the HIV/AIDS epidemic. Already people in remote areas of the province are dying of AIDS-related illnesses, yet HIV/AIDS awareness and prevention campaigns are yet to reach these areas and there is little scope for future intervention. How are messages about preventative measures to reach the most remote corners of the province when the schools and health centres have shut, and people lack even the most rudimentary health services? In places like Kopiago those most at risk are the generation of young people who have missed out on formal education - a cohort of young people who are neither literate, nor fluent in Tok Pisin.

In rural areas throughout the highlands, people are now dying from AIDS-related illnesses, and these deaths are being blamed on witchcraft and 
sorcery (Post-Courier 13 May 2004). Women in the Southern Highlands and elsewhere in Papua New Guinea are, as a result, being tortured and killed in trials of increasing regularity. In December 2003 one such witch trial occurred at Lake Kopiago (see Haley 2004). During the course of this witch hunt and trial six women were held captive and repeatedly tortured over the space of a fortnight. One woman died as a result and the others sustained horrific disabling injuries. The attackers in this instance were boys in their late teens - boys who have missed out on the opportunity for formal schooling due to school closures and teacher shortages. This event and others in the area have not been formally investigated and it is unlikely that the perpetrators will be punished as there are no police or magistrates in the Kopiago sub-district.

Contemporary witch hunts and trials being reported across the highlands appear to be linked to the burgeoning HIV/AIDS epidemic. The Kopiago witch trial, for example, was precipitated by the first instances of AIDS-related deaths in the area, and the women who were tortured were accused of killing a young man who most likely died of AIDS-related tuberculosis. The link to AIDS, the breakdown of essential services, and the emergent practice of witch hunts in which women accused of witchcraft are violently tortured alerts us to the possibility that Papua New Guinea's HIV/AIDS epidemic not only has huge public health and development implications but that it looms as an unresolved law and order issue.

\section{Conclusion}

It is clear that conflict and disorder in the Southern Highlands are not amenable to simple explanations or easy solutions. Fighting appears to have been a historic feature of social relations in the Southern Highlands. But the nature of conflict and the mechanisms available to control conflict and promote reconciliation have been irrevocably changed by the colonial experience, the expansion of inter-group relations which the Australian administration set in train, and the introduction of an overarching state - no matter how tenuous the state's presence might have been in some parts of the province. The intrusion of large resource projects has also had a major, though uneven impact on Southern Highlands' communities, both culturally and materially, by generating new income flows and at times providing community services which the state has been unable to provide.

Despite the revenue generated by these resource projects, there is little evidence of the benefits that this wealth might have been expected to bring. Royalties are consistently alleged to have been misused and squandered and far from improving the well being of Southern Highlands communities, these new sources of revenue have created new sources of friction within and between communities, such that Southern Highlanders are now fighting for access to the 
limited state delivered services and to the benefits and services resource developers can provide.

At the same time, the declining capacity of the state to assert its authority against raskol gangs, local 'warlords' and corrupt politicians has undermined the state's legitimacy and fostered a downward spiral of weak governance, lawlessness and violent conflict. One manifestation of this has been the failure of elections in the province, at both national and local levels, and as a consequence the effective disabling of the provincial assembly.

Unchecked conflict is, of course, a serious impediment to development, and it is all well and good to better understand the roots of conflict in the Southern Highlands, but where does that leave us? What can be done to improve the situation for Southern Highlanders? Hanson et al (2001:313) recommend that 'disadvantaged districts' be formally incorporated into national policies so that the inequalities they identified at district levels might be addressed. On the basis of their study Southern Highlands was one of the most disadvantaged provinces with five of the eight districts being rated as either extremely disadvantaged or seriously disadvantaged with respect to the rest of Papua New Guinea.

Until the overall level of disadvantage throughout the Southern Highlands is improved the distribution of resources will remain a source of conflict. The problems facing the Southern Highlands need therefore to be addressed as a matter of urgency, because as the post-election violence which accompanied the 2002 national elections demonstrated, political instability in the highlands can and does affect the flow of resources throughout the country.

The Southern Highlands does of course provide several development conundrums. Good governance relies on public servants being in place and doing their jobs - police, magistrates, teachers and health workers are needed on the ground throughout the province. They need to be supported by a functioning administration. However at present there is negligible infrastructure in the western end of the province, so one of he the first challenges is how to encourage public servants back into these areas.

It is also difficult for donors to provide service delivery in areas which are effectively under siege, and this is another problem presented by SHP. Places such as Mendi and Tari (the two largest population centres) are difficult to work in due to lawlessness and fighting. Whereas more remote places which are relatively safe, miss out on essential services because they are further down the line.

If funds and resources could somehow be channelled into these remote areas, benefits would no doubt flow, because civil society stills exists in these areas, and lawlessness is not the problem it is in the larger centres. This is a real challenge for donors. Small scale community level development focussed on the 
more remote parts of the province will most likely result in more immediate successes and more general successes throughout the province in the longer term (see Vail, this volume). Indeed many of the workshop participants agreed that the idea of small successes needs to be more fully explored, and that in seeking solutions to the problems which have beset the Southern Highlands we must seek to harness local initiatives and 'aggregate the small successes'.

\section{References}

Ballard, J. A. 1983 'Shaping a political arena: The elections in the Southern Highlands'. In D. Hegarty (ed.), Electoral Politics in Papua New Guinea: Studies on the 1977 National Elections. Port Moresby: University of Papua New Guinea, pp.174-195.

Bourke, R. M. 2001 'An overview of food security in $\mathrm{PNG}^{\prime}$, in R.M. Bourke, M.G. Allen and J. G. Salisbury (eds), Food Security in Papua New Guinea. Canberra: Australian Centre for International Agricultural Research, pp. 5-22.

Bourke, R. M., Allen, B. J., Hide, R. L, Fritsch, D., Grau, R., Hobshawn, P., Konabe, B., Levell, M. P., Lyon, S., and Varvaliu, A. 1995 Agricultural Systems of Papua New Guinea Working Paper No.11: Southern Highlands Province. Canberra: The Australian National University.

de Albuquerque, K., and D'Sa, E. 1986 Spatial Inequalities in Papua New Guinea: A District-Level Analysis. Port Moresby: Papua New Guinea Institute of Applied Social and Economic Research.

Haley, N. C. 2004 'A failed election: the case of the Koroba-Lake Kopiago Open Electorate', in P. Gibbs, N. Haley and A. McLeod (eds), Politicking and Voting in the Highlands: The 2002 Papua New Guinea National Elections. State, Society and Governance in Melanesia Discussion Paper 2004/1. Canberra: State, Society and Governance in Melanesia Project, Research School of Pacific and Asian Studies, Australian National University, pp. 16-26.

Hanson, L. W., Allen, B. J., Bourke, R. M. and McCarthy, T. J. 2001 Papua New Guinea Rural Development Handbook. Canberra: The Australian National University.

National Statistical Office, Papua New Guinea (NSO) 2002 National Thematic Map Tables PNG 2000 National Census on CD-ROM. Waigani: NSO.

Newell, B. P. 1970 Lake Kopiago Patrol Report 4-1969/70.

Standish, B. 1996 'Elections in Simbu: towards gunpoint democracy?', in Y. Saffu (ed.), The 1992 PNG Election: Change and Continuity in Electoral Politics. Political and Social Change Monograph 23. Canberra: Department 
of Political and Social Change, Research School of Pacific and Asian

Studies, Australian National University, pp. 277-322.

2000 Electoral Governance in Papua New Guinea: Chimbu poll diary, June
2002. Cited at: http://rspas.anu.edu.au/melanesia/pngresourcepage.htm

Wilson, R. K. 1974 Socio-Economic Indicators Applied to Sub-Districts of Papua New Guinea. Melbourne: Melbourne University.

\section{ENDNOTES}

${ }^{1}$ Southern Highlands Province is home to the highly successful Kutubu, Gobe and Moran Oil Projects and the Hides Gas to Electricity Project, all of which are now operated by Oil Search Limited. These generate cash royalties and other non-cash benefits which are distributed between stakeholders (the national government, the Southern Highlands provincial government, local level governments and the SHP landowners directly). Gas from Hides is purchased by the Porgera Joint Venture (PJV) and used to generate electricity which in turn powers the Porgera Gold Mine located in Enga Province. This electricity is transmitted via a high-tension power line running through SPH. Southern Highlanders with land along the power line easement receive annual occupation fees while those living within the Lagaip-Strickland riverene corridor receive water use payments in respect of tailings, which are released into the river system. Southern Highlanders have benefited from several PJV initiated Tax Credit Scheme funded projects.

2 Phillip Moiya, SHP's Western Regional administrator, has recently reported that there were 164 conflict-related deaths in the Tari area alone in 2003 and a further 40 such deaths between January and August 2004 (see Lewis, this volume).

3 The 2000 national census records a population of 546,265 for the Southern Highlands Province, although it is likely that the actual population is much closer to 500,000 , based on the extrapolated 1980 census population using the 1980-1990 inter-census growth rate of 3.5 per cent. In several districts within SHP, population figures were inflated for political gain in preparation for the 2002 national election.

4 This figure is based on calculations from Bourke et al (1995).

5 It should be noted that resource projects elsewhere in Papua New Guinea have also failed to lower the overall level of disadvantage in the districts in which they are situated. For example, the Lagaip-Porgera district, home to the Porgera gold mine, was amongst the thirteen districts ranked as 'extremely disadvantaged' relative to all other districts in Papua New Guinea, as was the North Fly district, in which the Ok Tedi mine is situated. Interestingly, Telefolmin district, which supplies much of Tabubil's workforce, was the equal most-disadvantaged district, alongside Middle Ramu, home to the Ramu nickel mine.

6 The 2002/2003 national elections produced some electoral results inconsistent with this, in that a Duna candidate won the Koroba-Lake Kopiago seat despite the Huli commanding a huge electoral advantage (see Haley, this volume; 2004) while Hami Yawari (from Kutubu) won the provincial seat.

7 In 1992 the officially appointed ADA had aligned himself with Herowa Agiwa, so instead of taking up his appointment to Kopiago he spent the last term of government based in Koroba.

8 The north Hewa area was derestricted in 1971, only two years before self government and four years before independence. 